\title{
IBD: Progress in pathogenesis
}

Claudio Fiocchi, MD, SCOtt A Strong, MD, Gail A West, BA, John S Klein, MS

C FIOCCHI, SA STRONG, GA WeSt, JS KLEIN. IBD: Progress in pathogenesis. Can J Gastroenterol 1993;7(2):110-114. Limited progress has occurred in the search for new etiological agents. Trials with antituberculous drugs appear to benefit some patients with Crohn's disease, but isolation of Mycobacterium johnei from tissues continues to be sporadic. Genetic heterogeneity, suggested by clusters of patients with the same human leukocyte antigen or autoimmune markers, may predispose to inflammatory bowel disease (IBD). Identification of dominant regions of the $T$ cell receptor is being actively pursued with the hope of identifying an immune response to a restricted set of antigens. The potential relevance of autoantigens has been reinforced by their detection in the intestine $(40 \mathrm{kDa}$ protein) and presence of circulating autoantibodies. Levels of cytokines in the circulation tend to reflect clinical activity, whereas their presence in the inflamed gut may identify factors responsible for local damage. In addition to epithelial cells, the role of intestinal fibroblasts, muscle cells and endothelial cells in inflammation is being explored. Interest in animal models of IBD is gaining increasing support, mostly to test inhibitors of inflammation. This expanding knowledge in the pathogenesis of intestinal inflammation is generating new therapies. Lipoxygenase inhibitors, leukotriene receptor antagonists, cytokine antagonists, new immunosuppressors, and antibodies to CD4 $+T$ cells and adhesion molecules are all under active investigation.

Key Words: Animal model, Inflammatory bowel disease, Mucosal immunity, Predisposing factors, Therapy

\section{Maladie intestinale inflammatoire: progrès en pathogenèse}

Des progrès ont été accomplis dans la recherche de nouveaux agents étiologiques. Les essais sur des médicaments anti-tuberculeux semblent démontrer leur effet bénéfique chez certains patients atteints de maladie de Crohn, mais l'identification de Mycobacterium johnei dans les spécimens tissulaires continue d'être sporadique. L'hétérogénéité génétique, suggérée par des groupes de patients porteurs des mêmes HLA ou marqueurs auto-immuns, pourrait les prédisposer à la maladie intestinale inflammatoire. L'identification de zones dominantes de récepteurs des cellules $T$ se poursuit activement, dans l'espoir d'identifier une

Department of Gastroenterology and Research Institute, Cleveland Clinic Foundation, Cleveland, Ohio, USA

Correspondence and reprints: C Fiocchi, Department of Gastroenterology and Research Institute, Cleveland Clinic Foundation, 9500 Euclid Avenue, Cleveland, OH 44195, USA
W ITH THE CONTINUOUS ADVAN. ces in the field of mucosal im. munity and the characterization of various pathways involved in inflam. matory responses, considerable progress has been made in the understanding of intestinal inflammation. Consequent. ly, this has greatly improved knowledge of the biological, cellular and moleculat mechanisms of inflammatory bowel disease (IBD) - Crohn's disease and ulcerative colitis. Once the most im. portant mechanisms of gut inflamma. tion are understood, it will be feasible to block them in a very specific and efficient manner, leading the way to truly effective forms of therapy.

The present challenge is to deter. mine which of the several potential etiopathogenic factors (genetic, dietary, environmental, microbiologi. cal) is the most critical in activating the mucosal immune system, and which of the many cell types (plasma cells, T cells, macrophages, neutro. phils, etc) or secreted substances (antibodies, eicosanoids, cytokines, oxygen radicals, etc) are directly responsible for tissue injury and should be targeted for specific blockade (1). Thus, the current status of progress in the pathogenesis of IBD can be defined as a phase of transition 'from mechanisms to therapy'. Recent developments in this transition phase are reviewed. 
réponse immunitaire à un groupe restreint d'antigènes. L'importance potentielle des auto-antigènes a été confirmée par leur présence dans l'intestin (protéine 40 $\mathrm{KDa}$ ) et par la présence d'auto-anticorps circulants. Les taux de cytokines dans la circulation tendent à refléter l'activité clinique, alors que leur présence dans l'intestin inflammé peut identifier les facteurs responsables de lésions locales. En plus des cellules épithéliales, le rôle des fibroblastes intestinaux, des cellules musculaires et endothéliales est étudié dans le processus inflammatoire. L'intérêt croît pour la maladie intestinale inflammatoire dans des modèles animaux, surtout en ce qui a trait aux inhibiteurs de l'inflammation. Cet approfondissement des connaissances sur la pathogenèse de l'inflammation intestinale, entraine la mise au point de nouvelles thérapeutiques. Les inhibiteurs de la lipoxygénase, les antagonistes des récepteurs des leucotriènes et des cytokines, de nouveaux immunosuppresseurs et les anticorps anti-cellules CD4 $+\mathrm{T}$ et les molécules d'adhésion, font tous l'objet de recherches.

\section{MICROBIOLOGY}

The wave of excitement about a possible mycobacterial etiology of Crohn's disease is declining. This is due mostly to the inconsistent rate of recovery of Mycobacterium paratuberculosis organisms or DNA from involved tissues, and the few but consistent positive findings in control normal bowel $(2,3)$. Nevertheless, antituberculous drugs appear to benefit at least some patients with Crohn's disease (4), although it is unclear whether this is a direct effect on the Mycobacterium paratuberculosis or is caused by changes in the composition of the intestinal bacterial flora. Sophisticated techniques, such as the use of a polymerase chain reaction that allows detection of minute amounts of microorganism-specific DNA, may provide new clues to the precise identification of previously obscure agents, as recently demonstrated in Whipple's disease (5).

\section{ENVIRONMENTAL, GENETIC AND OTHER PREDISPOSING FACTORS}

No major developments have occurred in the detection of new environmental factors, and the possible role of socioeconomic status, climate, diet, smoking, pollutants, etc, is still unclear. Some progress, however, is being made in consolidating the concept of genetic heterogeneity in IBD (6). Among multiple potential candidate genes, an association with HLA-DR2 has been confirmed in American patients with ulcerative colitis, while in a com- parable population Crohn's disease is significantly associated with the HLADR1/DQw5 phenotype (7). In addition, the finding of antineutrophil cytoplasmic antibodies in healthy family members of ulcerative colitis patients has raised the possibility that these antibodies may represent a marker of genetic susceptibility in this condition, independent of HLA class II antigen expression (8). The relevance of mucin abnormalities and increased intestinal permeability, previously heralded as potential predisposing factors, has been recently challenged in face of reports showing that mucin class IV deficiency may exist in the absence of ulcerative colitis (9), and that patients with Crohn's disease and their unaffected relatives may have normal absorption of marker molecules (10).

\section{ANIMAL MODELS}

Until recently animal models of intestinal inflammation have been considered to be of limited value because of their acute, self-limited nature and only distant relatedness to human IBD (11). Nevertheless, even acute experimental mucosal inflammation can be very useful for testing new anti-inflammatory agents, and their use is now increasing in parallel with the expanding arsenal of new therapeutic options (12). The search for animals with spontaneous intestinal inflammation has produced a new promising model, the $\mathrm{C} 3 \mathrm{H} / \mathrm{HeJ}$ inbred strain of mice, which exhibits an apparently heritable form of colitis (13). An even more sophisticated approach to creating novel colitis models can be undertaken by adopting molecular engineering, a system in which selected genetic information is transmitted by inoculation of specific DNA into a host animal, which will then express phenotypic manifestations related to the characteristics of the injected genes. The practical feasibility of this approach has been proven by the induction of small and large bowel inflammation in rats transgenic for the human HLA-B27 genes (14). An expanded utilization and screening of animals transfected with a variety of genes may lead to the development of new models more closely resembling human disease, and perhaps the identification of genes controlling inflammatory responses in the gut.

\section{MUCOSAL IMMUNITY}

During the last decade mucosal immunity has occupied a position of dominance in the study of IBD pathogenesis, and this is likely to continue for the foreseeable future (15). Although intestinal immune cells are at the centre of attention, the approach to their evaluation is progressively changing. In addition to defining the immunoregulatory role of mucosal $\mathrm{T}$ cells, and searching for related dysfunctions associated with IBD, attention is being focused on the way that these cells recognize antigens through their $\mathrm{T}$ cell receptors. To accomplish this, different regions (variable regions, $V$ ) of the $\alpha$ and $\beta$ chains of the T cell receptor are used depending on the unique molecular structure of the antigen presented in association with HLA surface molecules (forming the so-called trimolecular complex). There are several examples of over or underutilization of $\mathrm{V} \beta$ regions of the T cell receptor in autoimmune diseases, as reported in rheumatoid arthritis and autoimmune thyroiditis $(16,17)$. This implies that a restricted or predominant antigen(s) may be involved in triggering specific $T$ cells, and could provide clues to the nature of such antigen(s). Preliminary evidence for abnormal utilization of the $T$ cell receptor in IBD has been recently presented, showing decreased expression of V $\beta 2$ 
TABLE I

Possible effects of mucosal immune system on intestinal cells in inflammatory bowel disease

\begin{tabular}{ll} 
Epithellum & $\begin{array}{c}\text { Proliferation, secretion, mucus release, induction of secretory } \\
\text { component and HLA-DR antigens, antigen presentation }\end{array}$ \\
Muscle cells & Proliferation, hypertrophy, contraction, collagen deposition \\
Endothelium & Activation, HLA-DR expression, antigen presentation \\
Fibroblasts & Proliferation, hypertrophy, collagen deposition \\
Nervous fibres & Modulation of neuropeptide secretion \\
\hline
\end{tabular}

genes in lamina propria $\mathrm{T}$ cells of Crohn's disease and ulcerative colitis tissues, and expression of V $\delta 3$ genes among intraepithelial lymphocytes from ulcerative colitis specimens $(18,19)$.

While the detailed study of mucosal immune cells is essential to the understanding of the mechanisms of tissue damage in IBD, the investigation of the soluble mediators of inflammation derived from those cells is also generating information with important diagnostic and therapeutic implications. The intestinal mucosal cytokine network is extremely complex, and even more so in Crohn's disease and ulcerative colitis (20). However, the cell source, distribution, concentration and measurement of selected cytokines in various compartments of the body is potentially of great value in confirming diagnoses, assessing clinical activity and devising new anti-inflammatory strategies. For instance, serum levels of soluble interleukin (IL) - 2 receptor can be positively correlated with the Crohn's disease activity index (21), whereas circulating levels of IL 6 are elevated in Crohn's disease but not ulcerative colitis patients $(22,23)$. Tumour necrosis factor $\alpha$ (TNF $\alpha)$ is elevated in both the peripheral blood and stools of children with active IBD $(24,25)$. Quite recently, an imbalance of ILl, one of the most potent pro-inflammatory cytokines, and its receptor antagonist (IL-lra), a natural anti-inflammatory protein, has been shown to be present in IBD mucosa (26). If confirmed, this would suggest that exogenous supplementation of additional IL-Ira to patients with active disease may re-establish a normal Ill-IL-lra equilibrium, thus blocking the deleterious effects of excessive amounts of
IL-1 in the gut, and resulting in anti-inflammatory activity.

A very novel aspect of mucosal immunity is the recognition of an increasingly important role of the so-called 'nonimmune cells' in modulation of local events in physiological and pathological conditions. In addition to the intraepithelial lymphocytes and the mononuclear cells of the lamina propria, the intestinal mucosa contains epithelial, muscle and endothelial cells, as well as fibroblasts. All these cell types have the demonstrated or potential capacity for carrying on immune functions, such as antigen presentation, immunoregulation and secretion of soluble mediators. The ability of gut epithelium to display class II (HLA-DR) antigens is well established (27). The functional counterpart of this phenomenon is the epithelial cells' capacity to present antigen (28). This function can be abnormal in IBD and perhaps contributes to the pathogenesis of this condition (29). Theretributing to the pathogenesis of IBD more actively than previously thought. This concept is further supported by epithelial cells produce the potent proinflammatory lipid mediator plateletactivating factor, and that its production is significantly elevated in ulcerative colitis (30). Intestinal fibroblasts generate large amounts of collagen, even more so when they are derived from strictured areas of Crohn's disease (31). This again demonstrates how mucosal mesenchymal cells may be critical in the development of some of the most characteristic manifestations of IBD.

Current investigations in the fore, the gut epithelium may be conthe recent demonstration that authors' laboratory show that intestinal muscularis mucosae cells and mucosal fibroblasts also respond to immune cellderived cytokines: both cell types proliferate when exposed to recom. binant IL-I, IL- 6 and TNF $\alpha$, a combination of them, or mixtures of natural cytokines contained in lamina propriagenerated culture supernatants (32). Furthermore, the effect of IL-L on these cells results in the induction of IL- 6 and procollagen mRNA (Strong et al, unpublished data). All these observations indicate that the mucosal inflam. matory response in IBD is much more complex than previously considered, with the involvement of ectodermal, endodermal and mesenchymal cells. As a consequence, the local cytokine network cannot be restricted to immune cells and cytokines, but must be ex. panded to include nonimmune cells and factors, all of them mutually acting upon and modulating each other. The possible immune-nonimmune cell in. teractions in the mucosa and their effects in IBD are summarized in Table 1.

\section{FROM MECHANISMS TO THERAPY}

Until now the treatment of both Crohn's disease and ulcerative colitis has been based on a poorly defined rationale and an empiric approach, mostly centred on administration of non. specific anti-inflammatory agents. Aminosalicylates and corticosteroids have been used by clinicians and gastroenterologists for a long time with good to satisfactory results for some but not all patients, and their relative effectiveness is probably due to a broad al. though non-specific antiinflammatory activity (33). Immunosuppressive drugs (azothioprine, 6-mercaptopurine, methotrexate) were later introduced in an attempt to help the most difficult patients (34), but even the most recent and potent substances (cyclosporine A, FK506) have important sideeffects, substantial toxicity and limited indications. This situation is due to lack of basic knowledge of the cause and pathogenic mechanisms of IBD. Although the precise cause(s) remain unknown, considerable advances have been made in the pathogenesis, allow. 
ing a much more precise and promising therapy to be envisaged in the near future.

At present, the logical choice for main targets of treatment in IBD should be the soluble mediators which, after being released by a multitude of activated mucosal cells, are likely to directly or indirectly cause inflammatory damage. These mediators are represented by a rather large and heterogeneous group of substances, including leukotrienes, thromboxanes, platelet-activating factor, cytokines (IL-1, IL-6. IL-8, TNF $\alpha$, etc) and oxygen free radicals (35). Specific inhibitors, blockers or antagonists are being developed, with very promising

\section{REFERENCES}

1. Fiocchi C. Pathogenesis and clinical implications: Where do we stand, where do we go? In: Goebell H, Ewe K, Malchow H, Koelbel C, eds.

Inflammatory Bowel Disease. Progress in Basic Research and Clinical Implications. Lancaster: Kluwer Academic Publishers 1991:237-54.

2. Sanderson JD, Moss MT, Tizard MLV, Hermon-Taylor J. Mycobacterium paratuberculosis DNA in Crohn's disease tissue. Gut 1992;33:890-6.

3. Rosenberg WMC, Bell JI, Jewell DP. Mycobacterium paratuberculosis DNA cannot be detected in Crohn's disease tissues. Gastroenterology 1991;100:A611.

4. Kohn A, Prantera C, Mangiarotti R, Luzi C, Andreoli A. Antimycobacterial therapy and Crohn's disease: A randomized placebo controlled trial. Gastroenterology 1992;102:A647.

5. Wilson $\mathrm{KH}$, Blitchington $\mathrm{R}$, Frothingham R, Wilson JAP. Phylogeny of the Whipple's-diseaseassociated bacterium. Lancet 1991;338:474-5.

6. Rotter J1. Immunogenetic susceptibilities in inflammatory bowel disease. Can J Gastroenterol 1990;4:261-6.

7. Rotter JI, Wang S-J, Yang H, et al. Genetic heterogeneity between ulcerative colitis (UC) and Crohn's disease (CD) identified by molecular HLA class II association.

Gastroenterology 1992;102:A688.

8. Shanahan F, Duerr RH, Rotter JI, et al. Neutrophil autoantibodies in ulcerative colitis: Familial aggregation and genetic heterogeneity.

Gastroenterology 1992;103:456-61.

9. Tysk C, Riedelsen H, Lindberg EE, preliminary results in animal models (12,36,37).

In addition to anti-soluble mediator substances, investigators are also looking into alternate and sophisticated manipulations of the immune system to bring mucosal inflammation under control. The use of anti-CD4 monoclonal antibodies has shown very exciting preliminary results $(38,39)$. Blocking vascular adhesion molecules with monoclonal antibodies may also yield another way of preventing inflammatory cells from entering the interstitium and causing inflammation (40). A future approach may include the induction of oral tolerance once specific antigens are identified. It is unlikely

Panzini B, Podolsky D, Jarnerot G. Colonic glycoproteins in monozygotic twins with inflammatory bowel disease. Gastroernterology 1991;100:419-23.

10. Ruttenberg D, Young GO, Wright JP, Isaacs S. PEG-400 excretion in patients with Crohn's disease, their first-degree relatives, and healthy volunteers. Dig Dis Sci 1992;37:705-8.

11. Strober W. Animal models of inflammatory bowel disease - An overview. Dig Dis Sci 1985;30:3S-10S.

12. Cominelli F, Nast CC, Duchini A, Lee M. Recombinant interleukin-1 receptor antagonist blocks the proinflammatory activity of endogenous interleukin-1 in rabbit immune colitis. Gastroenterology 1992;103:65-71.

13. Sundberg JP, Elson CO. A heritable form of colitis in mice.

Gastroenterology 1992;102:A596.

14. Hammer RE, Maika SD, Richardson JA, Tang J-P, Taurog JD. Spontaneous inflammatory disease in transgenic rats expressing HLA-B27 and human $\beta 2 \mathrm{~m}$ : An animal model of HLA-B27-associated human disorders. Cell 1990;63:1099-112.

15. Fiocchi C. Immunology of inflammatory bowel disease. Current Opinions Gastroenterol 1991;7:654-61.

16. Paliard X, West SG, Lafferty JA, et al. Evidence for the effects of a superantigen in rheumatoid arthritis. Science 1991;253:325-9.

17. Davies TF, Martin A, Concepcion ES, Graves P, Cohen L, BenNum A. Evidence of limited variability of antigen receptors on intrathyroidal $\mathrm{T}$ cells in autoimmune thyroid disease. N Engl J Med 1991;325:238-44.

18. Duchmann R, Strober W, Fiocchi C, James SP. TCR V $\beta 2$ gene expression is that all these new forms of treatment will be equally effective, but some will emerge as truly new weapons against IBD, while others will retain a secondary or complementary role. Finally, it should be remembered that patients with Crohn's disease and ulcerative colitis, although sharing some common pathogenic mechanisms, probably have some unique pathways of inflammation of their own, and perhaps even for different manifestations in various clinical subgroups. Therefore, one should consider that combinations of two or more inflammatory blockers, or combinations of new and old drugs, may be the way of achieving the most efficacious results.

selective in control but not in IBD lamina propria lymphocytes. Gastroenterology 1992;102:A617.

19. Landau SB, Balk SP, Yang L, Burke SK, Blumberg RS. T-cell receptor (TCR) $\delta$ variable region. utilization is altered in ulcerative colitis. Gastroenterology 1992;102:A650.

20. Fiocchi C. Cytokines. In: MacDermott RP, Stenson W, eds. Inflammatory Bowel Disease. New York: Elsevier. 1992:137-62.

21. Mueller C, Knoflach P, Zielinski CC. $\mathrm{T}$-cell activation in Crohn's disease. Increased levels of soluble interleukin-2 receptor in serum and supernatants of stimulated peripheral blood mononuclear cells. Gastroenterology 1990;98:639-46.

22. Gross V, Andus T, Caesar I, Roth M, Scholmerich J. Evidence for continuous stimulation of interleukin-6 production in Crohn's disease. Gastroenterology 1992;102:514-9.

23. Mahida YR, Kurlak L, Gallagher A, Hawkey CJ. High circulating levels of interleukin 6 in active Crohn's disease but not ulcerative colitis. Gut 1991;32:1531-4.

24. Murch SH, Lamkin VA, Savage MO, Walker-Smith JA, MacDonald TT.

Serum concentrations of tumour necrosis factor a in childhood chronic inflammatory bowel disease. Gut 1991;32:913-7.

25. Braegger CP, Nicholls S, Murch SH, Stephens S, MacDonald TT. Tumour necrosis factor alpha in stool as a marker of intestinal inflammation. Lancet 1992;339:89-91.

26. Cominelli F, Fiocchi C, Eisenberg SP. Bortolami M. Imbalance of IL-I and 
IL-1 receptor antagonist in the intestinal mucosa of Crohn's disease and ulcerative colitis patients. Gastroenterology 1992;102:A609.

27. Mayer L, Eisenhardt D, Salomon P, Bauer W, Plous R, Piccinini L. Expression of class II molecules on intestinal epithelial cells in humans. Differences between normal and inflammatory bowel disease. Gastroenterology 1991;100:3-12.

28. Mayer L, Shlien R. Evidence for function of la molecules on gut epithelial cells in man. J Exp Med 1987; 166:1471-83.

29. Mayer L, Eisenhardt D. Lack of induction of suppressor T cells by intestinal epithelial cells from patients with inflammatory bowel disease. J Clin Invest 1990;86:1255-60.

30. Ferraris L, Klein J, Fiocchi C, Karmeli F, Eliakim R, Rachmilewitz D. Both epithelial and lamina propria mononuclear cells contribute to the enhanced platelet activating factor generation in inflammatory bowel disease. Gastroenterology 1992;102:A622.

31. Stallmach A, Schuppan D, Riese HH, Matthes H, Rieken EO. Increased collagen type III synthesis by fibroblasts isolated from strictures of patients with Crohn's disease. Gastroenterology 1992;102:1920-9.

32. Strong SA, West GA, Klein JS, Milsom JW, Fiocchi C. Inflammatory cytokines stimulate proliferation of intestinal mucosa mesenchymal cells. Gastroenterology 1992;102:A701.

33. Gaginella TS, Walsh RE. Sulfasalazine. Multiplicity of action. Dig Dis Sci 1992;37:801-12.

34. Hawthorne AB, Hawkey C]. Immunosuppressive drugs in inflammatory bowel disease. A review of their mechanisms of efficacy and place in therapy. Drugs 1989;38:267-88.

35. Eliakim R, Rachmilewitz D. Potential mediators in inflammatory bowel disease. Gastroenterol Int 1992;5:48-56.

36. Wallace JL, Keenan CM. An orally active inhibitor of leukotriene synthesis accelerates healing in a rat model of colitis. Am J Physiol 1990;258:G527-34.

37. Vilaseca J, Salas A, Guarner F, Rodriguez R, Malagelada J-R. Participation of thromboxane and other eicosanoid synthesis in the course of experimental inflammatory colitis. Gastroenterology 1990;98:269.7

38. Emmrich J, Seyfarth M, Fleig WE, Emmrich F. Treatment of inflammatory bowel disease with anti-CD4 monoclonal antibody. Lancet 1991;1:570-1.

39. Deusch K, Reiter C, Mauthe B, Riethmuller G, Classen M. Chimeric monoclonal anti-CD4 antibody therapy proves effective for treating inflammatory bowel disease. Gastroenterology 1992;102:A615.

40. Wallace JL, Arfors K-E, McKnight GW. A monoclonal antibody against the CD18 leukocyte adhesion molecule prevents indomethacin - induced gastric damage in the rabbit. Gastroenterology 1991;100:878-83. 


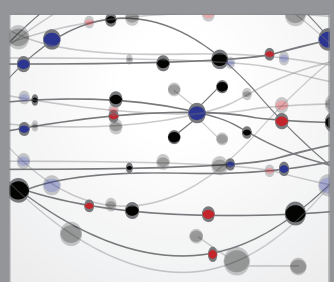

The Scientific World Journal
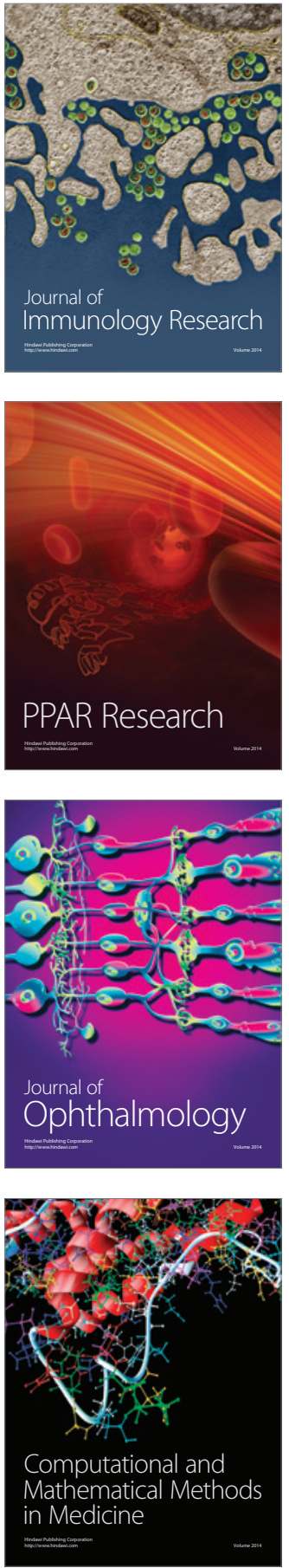

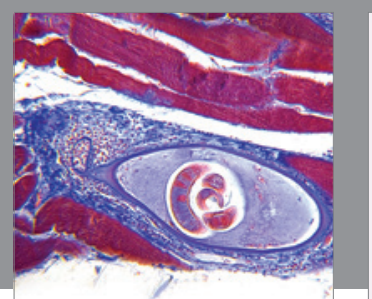

Gastroenterology Research and Practice

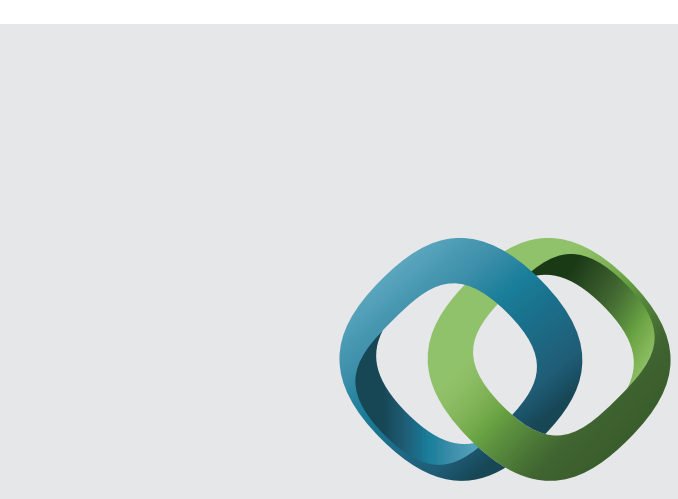

\section{Hindawi}

Submit your manuscripts at

http://www.hindawi.com
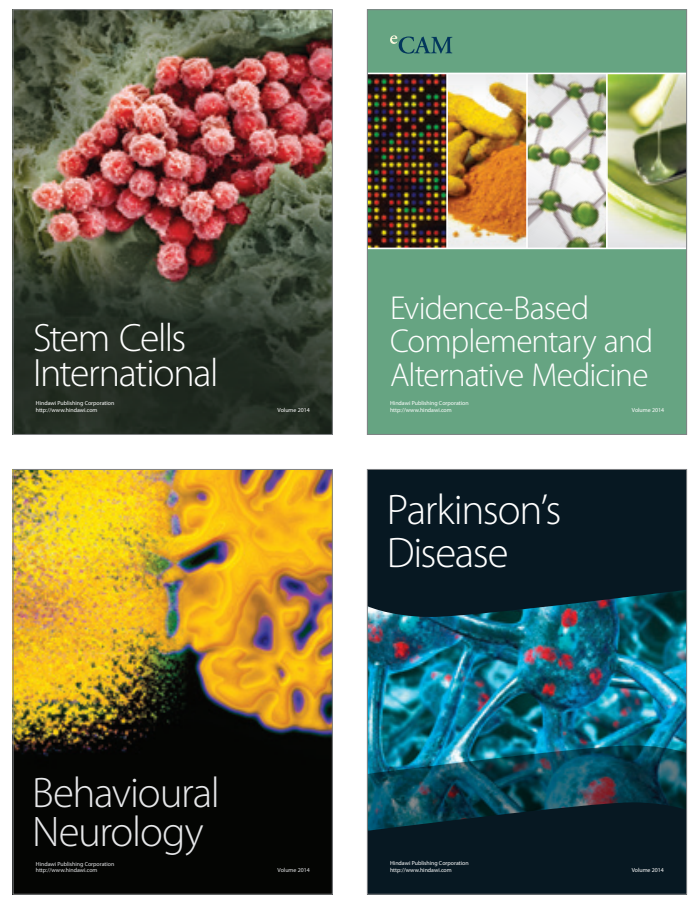
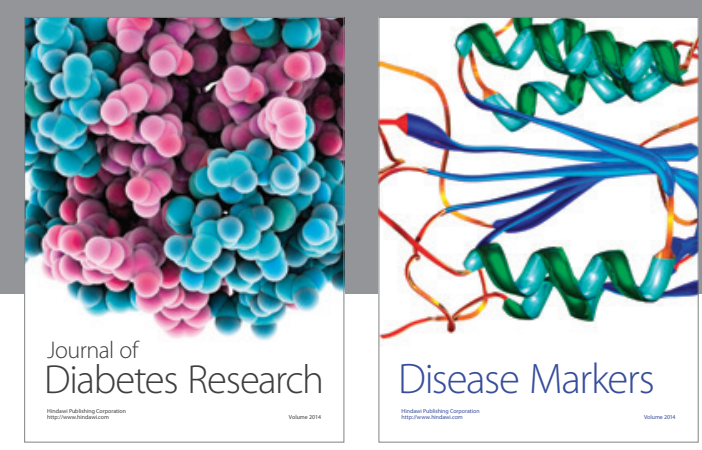

Disease Markers
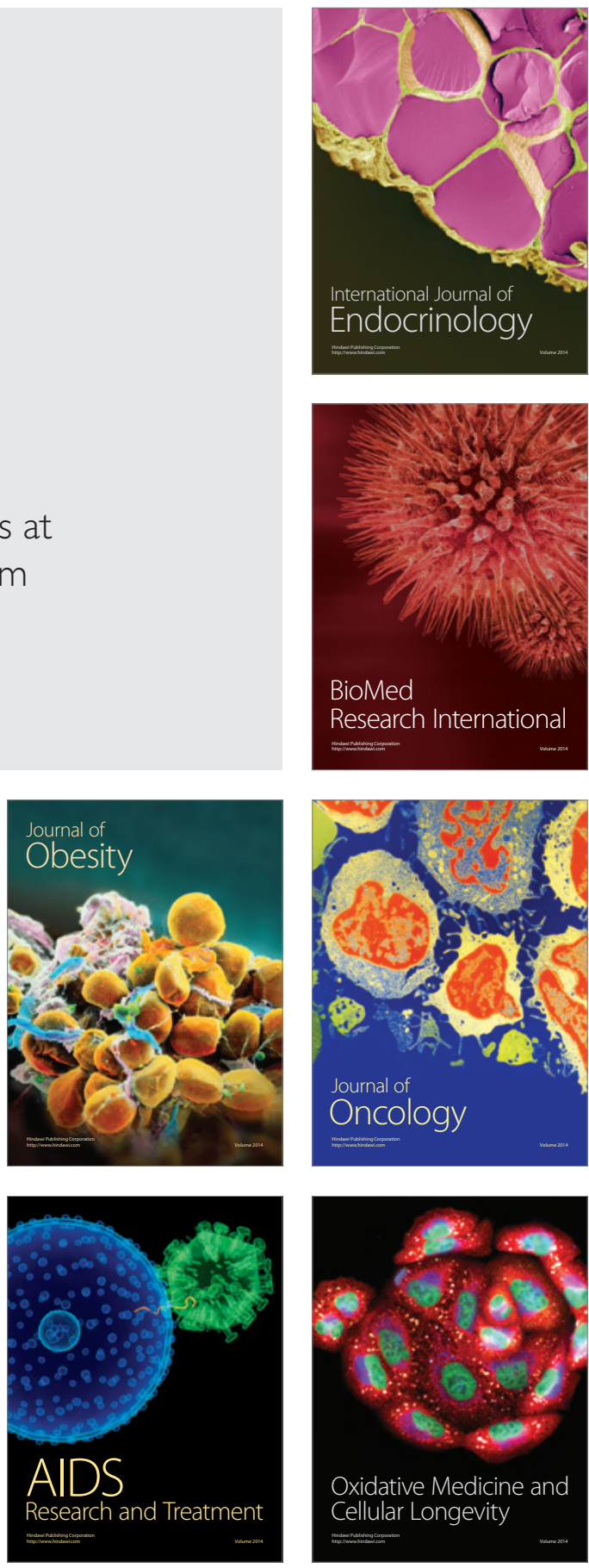